\title{
The trade-off between liquidity and insurance: voucher payments in a lab-in-the-field experiment with Colombian rural workers*
}

\author{
Alexander Cano ${ }^{\dagger} \quad$ Darwin Cortés ${ }^{\ddagger} \quad$ César Mantilla ${ }^{\S} \quad$ Laura Prada ${ }^{\mathbb{I}}$ \\ Medardo Restrepo"I
}

March 7, 2022

\begin{abstract}
We conduct a lab-in-the-field experiment in which 214 rural workers must choose between a cash or a voucher payment for completing a real-effort task. Participants face a twentypercent chance of suffering a negative shock that will reduce their cash payment by roughly two-thirds. Opting for the voucher reduces the likelihood of the shock by one-half. We employ a multiple-price list with a varying voucher payment and a fixed cash payment to study this trade-off relevant for expanding the coverage and contributions of rural labor formalization. We find that take-up rates go from $32 \%$ to $56 \%$, from the least to the more generous voucher. In a reference sample of undergrad students from the same region, take-up rates went from $17 \%$ to $33 \%$. Voucher redemption costs are exogenously manipulated by randomly assigning the show-up fee in cash or vouchers. Lower redemption costs induce a higher voucher take-up, but only among students. Being a rural worker with land, and receiving government subsidies in cash, predict a higher voucher take-up.
\end{abstract}

Keywords: agriculture; dual labor market; informal market;

JEL Classification Codes: C91, O17, R51

${ }^{*}$ We gratefully acknowledge the research assistance provided by Laura Acosta Bedoya, Julián Cárdenas Ospina, Merian Chica Otálvaro, Michael Marín Piedrahita, Juliana Olarte Zuluaga, José Santiago Rodas Vélez, Kelly Torres Hurtado, and Leidy Torres Quintero. We thank Margarita Gáfaro for her helpful comments. Financial Support from the program "Inclusión productiva y social: programas y políticas para la promoción de una economía formal, código 60185, que conforma la Alianza EFI, bajo el Contrato de Recuperación Contingente No. FP44842-220-2018." is gratefully acknowledged.

${ }^{\dagger}$ Justus-Liebig-Universität Giessen.

‡Department of Economics, Universidad del Rosario and Alianza EFI.

$\S$ Department of Economics, Universidad del Rosario. Corresponding author. e-mail: cesar.mantilla@urosario.edu.co Address: Calle 12C \# 4-69, Bogotá, Colombia.

II Department of Economics, Universidad del Rosario.

" Centro de Pensamiento, Universidad del Quindío. 


\section{Introduction}

The access to financial services and markets is limited in rural contexts (Besley, 1994). Insufficient access to credit contributes to the non-separability of farmers' production and consumption decisions (Benjamin, 1992, Jacoby, 1993). Therefore, households must adjust input allocation and labor supply to smooth consumption: it includes cropping patterns to smooth labor needs throughout the year (Fafchamps, 1993), and increases in the household's labor supply to cover unanticipated shocks and anticipated liquidity shortages (Jayachandran, 2006; Fink et al., 2020). The underpinnings of credit access and liquidity are relatively well understood regarding production decisions: loosening credit and liquidity constraints lead to higher input expenditures and the experimentation with more risky crops (Karlan et al., 2014; Ashraf et al., 2009); whereas fixed-price contracts, eliminating output price risks, produced results that are very similar to more complex and costlier contracts providing technical assistance and input loans (Arouna et al., 2021). By contrast, the relationship between consumption and credit constraints in rural contexts evokes questions that gain importance by recalling that most financial activities among the most vulnerable population aim to cover their basic needs (Collins et al., 2009; Karlan and Morduch, 2010). In this study, we explore the trade-off between liquidity and insurance in the context of informal labor markets and the co-existence of small landholders and landless rural workers.

Developing countries that are expanding their coverage of social security to rural areas may face two problems. First, in the presence of informal labor, the costs of expanding social security increase faster than the revenue from payroll taxes. Second, shocks have more persistent effects on health and educational outcomes given the limited means to self-insure (Rose, 1999: Alderman et al. 2006), in particular for those without assets. Inspired by the European voucher schemes that subsidize domestic services to reduce the informal economic activity (Grumiau, 2012; Marx and Vandelannoote, 2015), we want to test the attractiveness of a voucher payment in a rural setting. Given the importance of reducing exposure to shocks in rural contexts, we explore the acceptance of voucher payments knowing that they imply a reduction in workers' liquidity in exchange forbroadly speaking-insurance capabilities. We focus on labor supply, the side of the market that would benefit the most from where better coverage against shocks unrelated to production. Our insurance institution within the experiment is sufficiently abstract to avoid the mistrust that farmers might have on financial institutions or on the government's capability to execute insurance contracts; but also sufficiently simple and transparent to convey how the insurance operates in our game.

We conduct a lab-in-the-field experiment in a coffee-growing region of Colombia, an uppermiddle-income country with a self-employment rate of 51\% $\left.\right|^{1}$ the highest among OECD countries. Moreover, there are severe gaps between the urban and rural populations. For instance, the land is highly concentrated (Gáfaro et al., 2012), informal labor can be as high as 85\% in rural areas (Otero-Cortés, 2019), and insurance capabilities are limited, to the extent that households sacrifice food spending when they face health shocks (Cortés et al., 2021).

Participants were invited to an activity where they must complete a real-effort task and choose

\footnotetext{
${ }^{1} \mathrm{OECD}$ (2022), Self-employment rate (indicator). doi: 10.1787/fb58715e-en
} 
a payment method. They can opt for a payment in cash equal to the daily minimum wage $\left.\right|^{2}$ or a payment using a voucher. We employ a multiple price list (MPL) to elicit choices for four different voucher values, equivalent to 83,93,100, and 113 percent of the payment in cash. Participants knew they would be exposed to a negative shock that would reduce their earnings by two-thirds of the amount offered in cash. Risk exposure with the cash payment was $20 \%$, and it was reduced to $10 \%$ with the voucher payment. The negative shock was implemented with a dice roll, followed by a coin toss that would "save them" from the undesired dice outcome when choosing the voucher. The vouchers needed to be immediately redeemed to isolate the trade-off between liquidity and insurance from inter-temporal mechanisms. For instance, from the relationship between procrastination and inputs expenditure (Duflo et al., 2011), and from lack of liquidity as a commitment device (Casaburi and Macchiavello, 2019).

We find, for a sample of 214 rural workers from the coffee-growing region of Quindío, that the voucher take-up goes from 32\% for the least generous voucher (having an expected value $12 \%$ lower than the cash payment) to $56 \%$ for the most generous voucher (having an expected value $23 \%$ higher than the cash payment). These values are considerably larger compared to a sample of 69 undergraduate students in the capital city of Quindío: the take-up rate went from 16 to 33\% from the least to the most generous voucher.

We use the between-subjects variation to explore whether the transaction costs of voucher redemption affect the attractiveness of this payment method. We randomly assign a show-up fee payment (i.e., for participating) to be delivered in cash or vouchers. If the cost of voucher redemption is non-negligible, participants receiving the show-up fee in a voucher would be more likely to select the voucher payment for completing the real-effort task. We do not find support for this behavior in the rural sample, only in the students' sample.

We also induce random variation in the order in which we presented the four choices in each session. We found weak evidence for the field sample that the take-up rates in the field sample were higher when participants were presented first with the most generous voucher. Among students, the pattern is the opposite. We argue that this difference is explained by the high takeup of the most generous voucher among rural workers, causing some "endowment effect" for the insurance.

Vouchers are often used in field experiments to find optimal price subsidies (Dupas, 2014, De Janvry et al. 2017), encourage the purchase of subsidized health- and agriculture-related products (Cohen and Dupas, 2010; Duflo et al., 2011; Dupas, 2014; Hoffmann, 2018), and incentivize the attendance to specific events (Beam, 2016), to name a few examples. They have also been employed in experiments testing mechanisms that elicit willingness to pay (Burchardi et al. 2021 ). We contribute by revealing how likely rural farmers accept them as a partial payment method. When vouchers are subsidized, about one of every two participants from our rural sample find them acceptable. When vouchers have an expected value below cash, capturing labor formalization efforts according to current contribution rates, only one of every three participants finds them acceptable.

\footnotetext{
${ }^{2}$ We offer 30,000 COP. By the time we conducted the experiment, the daily minimum wage was 30,284 COP. Approximately 8 USD.
} 


\section{Experiment}

\subsection{Experimental design}

We employed an MPL setting that worked as follows. Upon arrival, participants were informed that they would need to perform a real-effort task and get paid for its completion. We also informed them that they could lose a considerable amount of their individual earnings at the end of the activity due to a negative shock. We do not eliminate uncertainty with the voucher payment, as it would be too attractive for participants in our game. They have to choose one of two options, combining a payment method and an absolute risk exposure:

- Cash: Receive 30 kCOP in cash. Face a $\mathbf{2 0 \%}$ chance of losing 20 kCOP.

- Voucher: Receive $V$ kCOP in a voucher. Face a $\mathbf{1 0} \%$ chance of losing $20 \mathrm{kCOP}$.

Participants took four decisions of this type, with $V \in\{25 ; 28 ; 30 ; 34\}$ [kCOP]. The scenario with $V=25$ mimics the current contribution rates to health and pension benefits in the Colombian labor market, corresponding to $17 \%$ of the income. In the scenario with $V=28$, we equalize the expected payoffs of the Cash and the Voucher options. As the expected payoff criterion will lead to indifference between the two options, this choice lets us know whether higher risk exposure with more liquidity is preferable. Similarly, the scenario with $V=30$ allows us to determine if, given the same benefit before the chance of a negative shock, participants prefer the cash option even if the risk exposure is twice as large compared to the voucher option. Finally, in the scenario with $V=34$, we provide one choice in which the voucher option has a larger value, before and after the chance of a shock, compared to the cash payment. Panel A on Table 1 summarizes the comparisons between cash and voucher payments for all four values of $V$.

We delivered the payments at the end of the session. For the vouchers, we gave participants a signed paper card with its redemption value written on it. We instructed participants to redeem the voucher for 90 minutes after the end of the session. This feature allows us to focus on instantaneous comparisons between payment methods, blocking inter-temporal mechanisms that have been explored in field experiments (Duflo et al., 2011; Casaburi and Macchiavello, 2019). The redemption occurred at a supermarket located within walking distance from where the experimental sessions took place. Participants had to redeem the total value of the voucher for the equivalent amount in supermarket products.

Our design included two between-subjects variations, randomized at the session-level. First, we randomly assigned whether the show-up payment of $10 \mathrm{kCOP}$ was provided in cash or a voucher. At the beginning of each session, we announced the corresponding payment method of this show-up fee. We aim at detecting whether redemption costs reduce the voucher's attractiveness. If these costs are non-negligible, participants who incur these redemption costs would be more willing to accept vouchers as a payment method: they already need to visit the supermarket to redeem part of their earnings. Second, we varied the display order of the four choices to control for order effects, as they may reveal that decisions are reference-dependent (i.e., whether the voucher becomes more or less attractive depending on the vouchers previously offered). In 
roughly half of our sessions, we employ an ascending order (i.e., from $V=25$ to 34), and in the remaining sessions, we use a descending order (i.e., from $V=34$ to 25).

\subsection{Implementation procedure}

The experimental protocol was approved by the Ethics Committee at Universidad del Rosario. Our protocol also included a set of rules to conduct in-person sessions during the pandemics. We interacted in ventilated areas, with a maximum of fifteen participants, mandatory use of mask for participants and the research team during the entire activity. We planned sessions with 10 to 12 participants, although some had lower attendance. Upon arrival, participants drew a numbered token that defined where they would be seated. We instructed the participants to keep this token until the end of the activity, as we would call them by this number to make their payments anonymous.

We started with the general instructions and described the payment method of the show-up fee. We then explained that they could receive the payment associated with the real-effort task in cash or vouchers, depending on their choice. Then, we mentioned the supermarket's name to make sure that all the participants knew where this store was located. We proceeded with the description of the cash and voucher options, emphasizing two aspects: (i) the voucher provided partial insurance against the chances of losing $20 \mathrm{kCOP}$ from their total earnings, and (ii) it was redeemable during a limited time after the activity.

We explained to participants that they would make four decisions, but only one would be used to compute their payments. We announced that the payment in cash would be the same across choices, but that we were interested in knowing "the payment in vouchers that would make this option attractive." Therefore, the voucher value in each scenario would be different.

We proceeded with the explanation of the real-effort task: Participants received a pot containing white and red beans and an empty pot. The task emulated manual chores involving coffee beans: separate the kidney beans by moving the red ones to the empty pot. We clarified that earnings depend on task completion, regardless of the time taken to separate the beans by color. We also informed participants that we would measure the time taken to complete the task even if it does not affect payments. After signing the informed consent, we proceeded to the decisionmaking phase. For each choice, we gave each participant a plastic card revealing the payments in cash and vouchers (see the left panel in Figure11). They needed to mark with an " $X$ " their preferred payment. The left panel displays an example of these cards.

We implement the shock using a dice roll. The dice have four green sides, one red side, and one blank side. If the roll outcome were "green," they would keep the received payment. If the roll outcome were "blank," they would roll again. If the roll outcome were "red," they would lose $20 \mathrm{kCOP}$ from their earnings. We included a coin toss to make the voucher's risk reduction more tractable. The numbered tokens delivered at the beginning were used as a coin. They also had a green and a red side. We explained that if the dice outcome was "red" and the participant chose the voucher, she had an additional opportunity of not losing the $20 \mathrm{kCOP}$ from their earnings. If the coin outcome was "green," the insurance from the voucher prevented the loss. The loss was effective only if the coin outcome was also "red." 
Figure 1: Experiment materials (translated from the original version in Spanish). Left panel: plastic card for a choice between cash and voucher. Right panel: poster with the summary of instructions for participants.
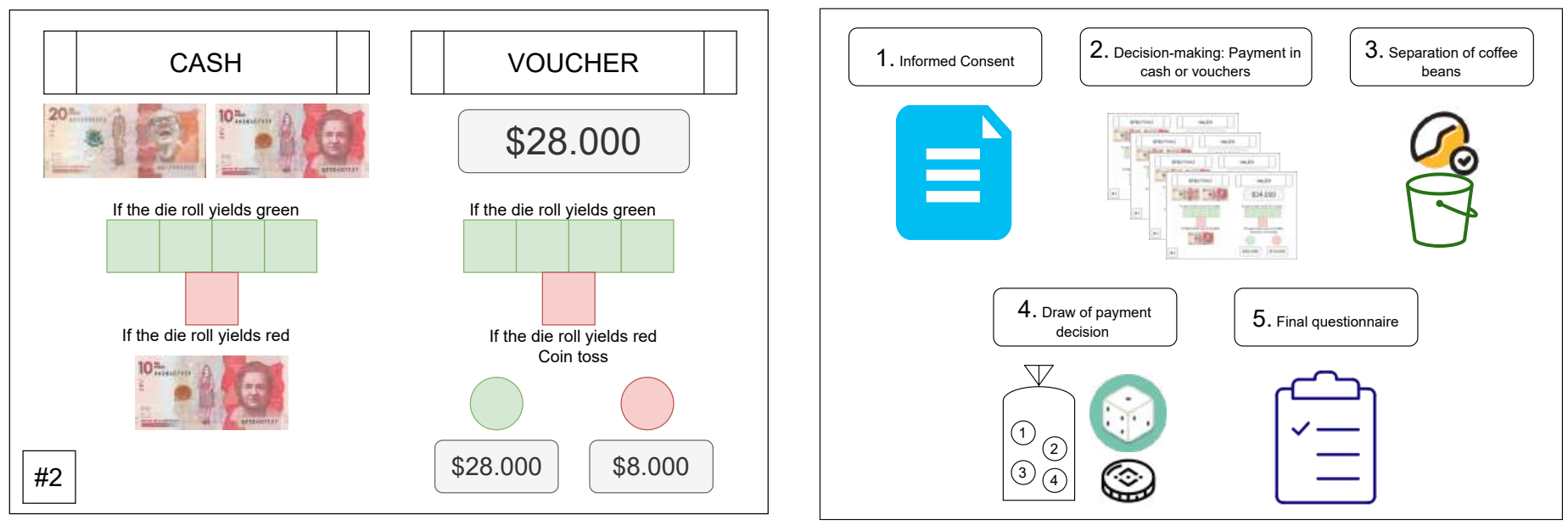

The right panel in Figure 1 displays a summary of the instructions, which was also presented as a poster to the participants. The real-effort task followed the decision-making process. We then proceeded with all the random draws to compute the payment decisions. A field assistant approached each participant, asking them to draw a numbered ball, from 1 to 4 , dictating the task chosen for payment. Then, each participant rolled the dice and tossed the coin. The reason for asking participants to toss the coin before double-checking if necessary is twofold. First, it helped to keep the anonymity in the decisions. Second, it speeded up the payoff resolution phase. We administered a survey to collect information regarding the participant's demographics, access to credit, and responses to health shocks.

\subsection{Sampling}

We conducted the experiment between July and August 2021 in the eleven rural municipalities of the Department of Quindío, located in the western central area of Colombia. The local offices providing technical assistance to farmers helped us recruit participants. We conducted two sessions per municipality (except in one case) ${ }^{3}$ Table A.1 in the Appendix A reports the total number of participants per municipality. Within each municipality, we varied the payment method of the show-up fee and whether the first or the second session was paid in cash. We randomized the order of choices between municipalities (see Table A.1). The sessions took place in rooms provided by local governments and lasted between 60 and 90 minutes. On average, participants earned 37,9 kCOP for their participation.

For comparability purposes, we conducted ten additional sessions with a total of sixty-nine

\footnotetext{
${ }^{3}$ In Salento, we conducted a single session. This municipality became a tourist hotspot, and farms are now more dedicated to the hospitality industry than to agriculture.
} 
students in Armenia, the capital city of Quindío, in September 2021. The low number of participants per session (6.9 on average) resulted from the class size restrictions for students attending in-presence sessions due to the pandemic. We invited undergrad students from Economics, Food Science, and Zootechnics to participate. The activity was part of one of their lectures, reducing the self-selection into the study. Moreover, the participants did not have previous experience in economic experiments. The amounts offered to participants in all choices between cash and vouchers were the same as in the original sample. The same fieldwork team conducted the sessions. We selected a supermarket close to the university to redeem vouchers, holding the same redemption rules from the lab-in-the-field experiment.

\subsection{Sample description}

We start with our rural sample. The average participant was 51 years old (std. dev. 16.9). Onethird of the participants were women, and $55 \%$ at most completed elementary school. The average income was $578 \mathrm{kCOP}$, corresponding to approximately 63 percent of the monthly minimum wage in Colombia. Twenty-one percent reported that they receive a monthly payment, whereas the rest receive more frequent-but also lower-payments. Twenty-nine percent reported that part of their payment is received in-kind. Regarding income, we also find that $29 \%$ of the participants receive any government subsidy. The average number of adults and children in their household was 2.8 and 0.6 , respectively.

As intended, our sample captures farmers with and without land. Thirty-six percent report having their own land and, among them, the most common crops are coffee (52\%) and plantain $(18 \%)$. Regarding social security, only 22 percent of the participants report being in the contributive health system. Fifty percent report having suffered any health problem in the past 12 months. When we asked them about their financial planning during their old age, $61 \%$ reported not making any plan, $16 \%$ have a mandatory pension plan, $8 \%$ a voluntary pension plan, and $10 \%$ said expecting help from their offspring. Informal credit networks also appear to be important in this rural context. When asked about who could lend them $50 \mathrm{kCOP}$ from one day to another, $29 \%$ replied that a friend, $18 \%$ a neighbor, and $13 \%$ a family member. Nonetheless, $35 \%$ also replied that they do not have a person to lend them this money.

Table A.2, in the Appendix, reports balance checks across treatments. The descriptive variables are balanced regarding variation in the show-up fee payment, randomized within municipalities. By contrast, and since we randomize the ordering of choices between municipalities, the following variables are unbalanced on this condition: age, marital status, education above elementary school, and whether the household belongs to the contributive or subsidized health system. These variables are included as controls in our regressions.

Regarding the students' sample, they are younger (24.5 years old, with a standard deviation of 6.6) and have more female representation (52\%). They report an average monthly income of 929 kCOP. Monthly payments are also more frequent (48\%), and belonging to the contributive regime is more widespread (54\%). Nonetheless, the access to government subsidies is relatively similar to the field sample (20\%). Fifty-seven percent reported having any health issue in the past 12 months. Fifty-one percent of students report that their family owns rural land. This percentage is 
1.41 times the frequency in the rural sample. Although it seems paradoxical at first sight, the most probable explanation is that $52 \%$ of the sample studied Zootechnics, and another $26 \%$ studied a short-duration program in Agrarian Sciences. Only the remaining 22\% studied Economics. Table A.3 reveals that all the characteristics are balanced across treatment arms.

\section{Results}

\subsection{Take-up rates of the voucher}

Panel B in Table 1 summarizes the percentage of participants who opted for the voucher with value $V \in\{25 ; 28 ; 30 ; 34\} \mathrm{kCOP}$ instead of a $30 \mathrm{kCOP}$ payment in cash. For $V=25$, the voucher is preferred by $32.2 \%$ of the participants. This number increases to $40.2 \%$ and $46.7 \%$ for $V=28$ and $V=30$, respectively. The most generous voucher, $V=34$, increases the take-up to $56.1 \%$. Table 1 also reports the comparison in take-up rates between treatment conditions. This is also depicted as cumulative distributions for the minimum value of voucher take-up in panels (b) and (d) from Figure A.1. in the Appendix. Differences by type of show-up fee reveal that, for $V \leq 30$, take-up rates are higher when the show-up fee is paid in cash. Nonetheless, the differences are not large enough to be statistically significant. This result, which will be explored further with a regression analysis, provides evidence against the "redemption costs" hypotheses.

The bottom of Panel B, and panels (c) and (e) from Figure A.1. compare the voucher take-up rates when the four choices were presented in descending versus ascending order. Take-up rates are higher when we start presenting the most generous voucher, $V=34$, compared to the opposite scenario, starting with $V=25$. This result suggests that reference points are important in the liquidity-insurance trade-off. Given the observed differences in the field sample, we conjecture that starting with the most attractive voucher increases the salience of the associated risk reduction.

\subsection{Comparison with the sample of students}

Panel C in Table 1 reports the aggregate outcomes for the sample of students. The take-up rates are considerably lower than in the field sample. The comparisons between treatment conditions for this sample reveal two additional differences for the field sample. First, students are more likely to choose the voucher if the show-up fee was paid as a voucher. Hence, and unlike in the field sample, the redemption cost hypothesis appears to explain differences in take-up rates. Recall that, according to this hypothesis, a voucher payment is more attractive if the show-up fee is paid in vouchers as well. Second, for the students, the vouchers were more attractive when they were presented in ascending rather than in descending order.

\subsection{Regression analysis: treatment effects}

We validate the findings from Table 1 using a regression analysis that lets us control for other factors and improves the computation of standard errors. The purpose is to understand treatment effects on the minimum price that a voucher needs to be chosen. A challenge for our econometric 
Table 1: Take-up of the voucher option compared to $30 \mathrm{kCOP}$ in cash.

\begin{tabular}{lcccc}
\hline & \multicolumn{5}{c}{ Voucher value (in kCOP) } \\
& $V=25$ & $V=28$ & $V=30$ & $V=34$ \\
\hline Panel A: Comparison with the Cash choice & & & & \\
Payment Voucher/Cash (without shocks) & 0.83 & 0.93 & 1 & 1.13 \\
$E($ Voucher) / E(Cash) & 0.88 & 1 & 1.07 & 1.23 \\
$E$ (Voucher) - E(Cash) & -3 & 0 & 2 & 6 \\
& & & & \\
Panel B: Voucher take-up in the field sample & & & & \\
Field sample (N=214) & 32.2 & 40.2 & 46.7 & 56.1 \\
& & & & \\
Show-up fee in voucher & 27.6 & 39.0 & 43.8 & 56.2 \\
Show-up fee in cash & 36.7 & 41.3 & 49.5 & 56.0 \\
$\chi^{2}$ test for type of show-up fee [p-value] & {$[0.155]$} & {$[0.739]$} & {$[0.401]$} & {$[0.973]$} \\
& & & & \\
Voucher prices in descending order & 41.7 & 46.9 & 52.1 & 59.4 \\
Voucher prices in ascending order & 24.6 & 34.7 & 42.4 & 53.4 \\
$\chi^{2}$ test for order [p-value] & {$[0.008]$} & {$[0.072]$} & {$[0.157]$} & {$[0.380]$} \\
& & & & \\
Panel C: Voucher take-up in the students' sample & & & & \\
Students sample (N=69) & 15.9 & 26.1 & 27.5 & 33.3 \\
$\chi^{2}$ test for field versus students' sample [p-value] & {$[0.009]$} & {$[0.035]$} & {$[0.005]$} & {$[0.001]$} \\
& & & & \\
Show-up fee in voucher & 17.1 & 34.3 & 40.0 & 45.7 \\
Show-up fee in cash & 14.7 & 17.6 & 14.7 & 20.6 \\
$\chi^{2}$ test for type of show-up fee [p-value] & {$[0.782]$} & {$[0.116]$} & {$[0.019]$} & {$[0.027]$} \\
& & & & \\
Voucher prices in descending order & 14.7 & 20.6 & 23.5 & 20.6 \\
Voucher prices in ascending order & 17.1 & 31.4 & 31.4 & 45.7 \\
$\chi^{2}$ test for ascending/descending order [p-value] & {$[0.782]$} & {$[0.305]$} & {$[0.463]$} & {$[0.027]$} \\
\hline
\end{tabular}


analysis is that 35\% (99 out of 283) of the participants never chose the voucher. We thus perform two econometric exercises that let us account for those participants. First, we run a tobit regression where the dependent variable is the minimum value required to choose the voucher. Here, we assume upper-level censoring and input the value of the most generous voucher $(34 \mathrm{kCOP})$ to the participants who always preferred cash. Second, we run an ordered logistic regression where we assign one level to each voucher value and add one final level for those participants who always preferred the cash (meaning that their minimum value is above $34 \mathrm{kCOP}$ ). We have in total five monotonic choices.

Whereas the tobit model has a more practical interpretation, the ordered logit accounts better for the large share of participants that always preferred the cash payment. Table 2 reports the coefficients for both exercises. Standard errors are clustered at the randomization level, the session. We have 31 sessions, 21 conducted in the field, and 10 conducted with students. Evennumbered models include municipal-level covariates. We cannot include municipal fixed effects because the descending order condition was randomized at the municipality level, except in one location. We start describing the results for the tobit model. In the sample of students, receiving the show-up fee as a voucher reduces the minimum voucher value that would be acceptable. However, adding this coefficient and its interaction with the field sample reveals that this effect is absent among farmers. 4 Farmers seem to accept vouchers of a lower value than students (about $4.3 \mathrm{kCOP}$ lower). Note that this value is no longer significant once we control for municipal-level covariates. Moreover, the interaction between a descending order of the choices and the dummy capturing the field sample becomes more negative, although it remains non-significant.

The results from the ordered logit, in models 3 and 4, are similar. We report the results as odds ratios to simplify the interpretation. However, it is important to remember that coefficients below one indicate a reduction in the odds of observing a participant selecting a higher-order choice, associated with a larger voucher value. Figure A.2 in the Appendix, let us observe the same results in terms of predicted take-up rates across treatments and samples. The effect of the show-up fee is congruent with our report from the tobit regression: the sum of this coefficient plus its interaction with the field sample reveals a null effect for the rural workers. Moreover, farmers are less likely to be classified into a higher category, but the effect is driven by those who face the four choices in descending order. Here, the interaction coefficient becomes statistically significant. Although the evidence is only suggestive, our interpretation is that the more generous vouchers increased the salience of the insurance. The decrease in the take-up rate from further reductions in the voucher price was partially counteracted by the loss of the insurance.

Table 2 also reports three municipal-level variables that are predictors of voucher take-up. Participants from municipalities with a higher index of formal employment deprivation (one component of the multidimensional poverty index) are more likely to accept vouchers with a lower price. By contrast, participants from municipalities with larger areas and larger average household sizes require vouchers of a larger value to prefer them over cash.

\footnotetext{
${ }^{4}$ In model 1 , this sum is 0.49 with a $p$-value 0.693 . In model 2 , this sum is 0.37 with a $p$-value 0.636.
} 
Table 2: Treatment effects on the price of accepted vouchers

\begin{tabular}{lcccc}
\hline & & & \multicolumn{2}{c}{ Ordered logit: } \\
& $(1)$ & $(2)$ & $(3)$ & $(4)$ \\
\hline Show-up fee in voucher & $-4.037^{* *}$ & $-3.917^{* *}$ & $0.374^{* *}$ & $0.367^{* *}$ \\
& $(1.943)$ & $(1.879)$ & $(0.151)$ & $(0.148)$ \\
Field sample & $-4.329^{*}$ & 0.339 & $0.339^{* *}$ & 0.893 \\
& $(2.386)$ & $(2.562)$ & $(0.170)$ & $(0.474)$ \\
Show-up fee in voucher $\times$ Field sample & $4.527^{*}$ & $4.292^{* *}$ & $3.285^{* *}$ & $3.410^{* * *}$ \\
& $(2.325)$ & $(2.077)$ & $(1.739)$ & $(1.560)$ \\
Descending order & -0.654 & -0.633 & 1.116 & 1.108 \\
& $(1.900)$ & $(1.832)$ & $(0.415)$ & $(0.406)$ \\
Descending order $\times$ Field sample & -1.235 & -3.084 & 0.499 & $0.345^{* *}$ \\
Formal employment deprivation & $(2.206)$ & $(2.058)$ & $(0.244)$ & $(0.159)$ \\
& & $-0.358^{* * *}$ & & $0.918^{* *}$ \\
Area $(k m 2)$ & & $(0.127)$ & & $(0.0311)$ \\
Average household size & & $0.0215^{* * *}$ & & $1.006^{* * *}$ \\
Constant & & $(0.00538)$ & & $(0.00172)$ \\
& & $9.304^{* * *}$ & & $15.53^{* *}$ \\
Observations & & $(3.267)$ & & $(17.82)$ \\
\hline
\end{tabular}

Additional control: whether the session was the first or second in the day. Other municipal-level covariates that are non-significant: unsatisfied basic needs in the municipal seat, ratio of cultivated area over total area, average age, percentage of married population at the municipality level. Clustered standard errors in parentheses. ${ }^{* * *} \mathrm{p}<0.01,{ }^{* *} \mathrm{p}<0.05,{ }^{*} \mathrm{p}<0.1$.

\subsection{Exploratory regression analysis}

We perform an additional econometric exercise of exploratory nature. Hence, we do not have an ex ante hypothesis on which participant's characteristics may predict the voucher take-up. Still, we can shed light on relevant variables for the field sample. We use a linear probability model with a panel data structure with each decision per participant as the unit of observation. This panel structure also lets us compute the marginal effect of increasing the voucher value on the take-up rate. We control for all the municipal-level covariates employed in the previous exercise, although we do not report their effects. We add the individual covariates in two sets. First, we add those related to the participant's demographic characteristics. Second, we add other variables that would hint at the participants' liquidity. Since we conducted twenty-one sessions in the field, clustering the standard errors at the session-level is problematic. We opted for a more stringent 
specification, with standard errors clustered at the participant level.

Table 3 reports the results of this regression. A $1 \mathrm{kCOP}$ increase in the voucher value increases its take-up by 3.2 percentage points. We report some marginally significant evidence that presenting the vouchers in descending order increases take-up. Agricultural laborers who reported not working in their own land were also less likely to opt for the voucher. We employ the nonincentivized measure of willingness to take risks proposed by (Dohmen et al., 2011) and find that participants reporting more risk-taking attitudes are more likely to opt for the voucher. This result contradicts risk-aversion predictions but can be explained by risk compensation: an adjustment in risk exposure in response to the (lower) perceived level of risk (Cohen and Einav, 2003; Evans and Graham, 1991). We also find that participants declaring that they are current recipients of any government subsidy are more likely to opt for the voucher. The most common reported subsidies in our sample were Familias en Acción, a transfer conditional on sending their kids to school; and Colombia Mayor, targeted to the elder population. Since both subsidies are delivered in cash, we rule out that this finding is driven by being accustomed to in-kind transfers.

We run a Tobit regression similar to the one reported in Table 2, with one observation per participant. We limit this exercise to the field sample, adding the covariates from Table 3 . The results, reported in Table A.4 in the Appendix, confirm that presenting the choices in decreasing order, a higher willingness to take risks, and receiving government subsidies reduce the minimum voucher value that becomes acceptable.

\section{Discussion}

The differences in treatment effects between our samples open two questions. First, why do the vouchers seem less attractive among students than rural workers? The take-up rate for the least generous voucher in the field sample is virtually identical to the take-up rate for the most generous voucher in the students' sample. The samples do not seem to considerably differ in their knowledge about rural production since $78 \%$ of the students were Zootechnics or Agrarian Science undergraduates. We argue that job opportunities and wealth differences partially explain the differences in take-up, as hinted in Tables 2 and 3 . Formal employment deprivation, one component of the multidimensional poverty index, increases the likelihood to accept vouchers offering lower amounts. At the individual level, having land, receiving government subsidies, and monthly payments were positively correlated with voucher take-up $\left.\right|^{5}$ Better access to labor markets and land, and a higher disposable income, increase the acceptability of vouchers. These are not necessarily good news since those in more need are also more reluctant to enter this payment scheme.

The second question is why paying the show-up fee in vouchers increases the voucher take-up among students but not among rural workers? Our conjecture on why we validate the "redemption costs" hypothesis among students, but not among rural workers, is that the latter already paid these costs by visiting the municipal seat. We aimed to increase participation rates by conducting the sessions over the weekends. However, rural workers coming to the session may have already planned to make their grocery shopping for the week (or month). We argue that this self-

\footnotetext{
${ }^{5}$ Monthly payments are correlated with a greater income (correlation coefficient is 0.23 with a $p$-value $<0.001$ ).
} 
Table 3: Linear probability model exploring individual predictors of voucher take-up

\begin{tabular}{|c|c|c|c|}
\hline & (1) & $(2)$ & (3) \\
\hline Voucher value & $\begin{array}{l}0.0322^{* * *} \\
(0.00549)\end{array}$ & $\begin{array}{l}0.0324^{* * *} \\
(0.00555)\end{array}$ & $\begin{array}{l}0.0324^{* * *} \\
(0.00556)\end{array}$ \\
\hline Show-up fee in voucher & $\begin{array}{l}-0.0443 \\
(0.0498)\end{array}$ & $\begin{array}{l}-0.0373 \\
(0.0496)\end{array}$ & $\begin{array}{l}-0.0398 \\
(0.0493)\end{array}$ \\
\hline Descending order & $\begin{array}{l}0.509^{* *} \\
(0.236)\end{array}$ & $\begin{array}{l}0.479^{*} \\
(0.244)\end{array}$ & $\begin{array}{l}0.471^{*} \\
(0.245)\end{array}$ \\
\hline Voucher value $\times$ Descending order & $\begin{array}{l}-0.0122 \\
(0.00766)\end{array}$ & $\begin{array}{l}-0.0122 \\
(0.00775)\end{array}$ & $\begin{array}{l}-0.0122 \\
(0.00776)\end{array}$ \\
\hline Women & & $\begin{array}{c}0.0450 \\
(0.0596)\end{array}$ & $\begin{array}{c}0.0298 \\
(0.0638)\end{array}$ \\
\hline Age & & $\begin{array}{c}0.00143 \\
(0.00201)\end{array}$ & $\begin{array}{l}0.000791 \\
(0.00201)\end{array}$ \\
\hline Agricultural laborer (no land) & & $\begin{array}{l}-0.151^{* *} \\
(0.0633)\end{array}$ & $\begin{array}{l}-0.132 * * \\
(0.0648)\end{array}$ \\
\hline Willingness to take risks & & $\begin{array}{l}0.0191^{*} \\
(0.00977)\end{array}$ & $\begin{array}{l}0.0233^{* *} \\
(0.00977)\end{array}$ \\
\hline Primary school or less & & $\begin{array}{l}-0.0441 \\
(0.0654)\end{array}$ & $\begin{array}{l}-0.0372 \\
(0.0664)\end{array}$ \\
\hline Married & & $\begin{array}{l}-0.0213 \\
(0.0691)\end{array}$ & $\begin{array}{l}-0.0141 \\
(0.0668)\end{array}$ \\
\hline Government's subsidy & & & $\begin{array}{l}0.0994^{*} \\
(0.0571)\end{array}$ \\
\hline Monthly salary & & & $\begin{array}{c}0.107 \\
(0.0708)\end{array}$ \\
\hline Payment in-kind & & & $\begin{array}{l}-0.0243 \\
(0.0555)\end{array}$ \\
\hline Constant & $\begin{array}{l}-0.171 \\
(2.682)\end{array}$ & $\begin{array}{c}0.832 \\
(2.739)\end{array}$ & $\begin{array}{c}2.110 \\
(2.805)\end{array}$ \\
\hline $\begin{array}{l}\text { Observations } \\
\text { R-squared }\end{array}$ & $\begin{array}{c}856 \\
0.091\end{array}$ & $\begin{array}{c}848 \\
0.133\end{array}$ & $\begin{array}{c}848 \\
0.146\end{array}$ \\
\hline
\end{tabular}

Municipality-level covariates in all regressions: formal employment deprivation, area, average household size, unsatisfied basic needs in the municipal seat, ratio of cultivated area over total area, average age, percentage of married population at the municipality level. Standard errors with clusters at the individual level in parentheses. ${ }^{* * *} \mathrm{p}<0.01,{ }^{* *} \mathrm{p}<0.05,{ }^{*} \mathrm{p}<0.1$. 
selection problem-the fact that invited farmers were already paying the transaction and transportation costs-would, if anything, represent an upper bound for our voucher take-up estimates. Rural workers that are less likely to enter into our sample due to transaction and transportation costs would also be less likely to visit the municipal seat to redeem the voucher.

Although we only have partial evidence, we provide a conjecture on why presenting the vouchers in descending value makes them more attractive for the agricultural workers but not for the students. We argue that more generous vouchers increased the salience of the additional insurance, but it only happened when the take-up rates were sufficiently large. For instance, a model with reference-dependent preferences in which reducing the voucher value is counteracted by the disutility of forgoing the insurance could explain this result.

\section{Concluding remarks}

We conducted a lab-in-the-field experiment to measure the trade-off between liquidity and insurance among Colombian rural workers in the coffee-growing region of Quindío. Participants must choose between a $30 \mathrm{kCOP}$ payment in cash, with a $20 \%$ probability of a negative shock subtracting 20kCOP from this payoff, or a voucher payment that reduced the likelihood of this negative shock to $10 \%$. When the voucher expected payment is lower than the expected value with cash, the take-up rate is $32 \%$. For the most generous voucher, with an expected value $23 \%$ higher than cash, the take-up rate increases to $56 \%$. We compare the results from the field with those obtained with undergraduate students from the main city in this region. Our findings suggest that rural participants have a higher valuation of the insurance provided by the offered vouchers. Within the rural sample, those more likely to accept vouchers have better job opportunities, access to land, and-presumably-a higher disposable income. This result suggests that it is much harder for the poorest rural workers, presumably more affected by a negative shock to give-up cash in exchange for insurance capabilities.

We explored this question as a first step to discuss whether a voucher scheme leading to the formalization of rural labor and granting better access to insurance opportunities would be sufficiently attractive. We observe a willingness to forgo liquidity for insurance capabilities. This result, and the other predictors of voucher take-up, are informative to think about specific policies that improve the rural workers' coverage against shocks unrelated to agricultural production.

We conceive two avenues for future research. First, it is imperative to understand the tangible insurance capabilities that rural producers and workers expect, knowing that in-kind payments are attractive in exchange for reducing risk exposure. Complex insurance mechanisms, such as weather-based insurance, have typical low take-up rates (Schickele, 2016). Our lab-in-the-field experiment gave us the advantage of simplifying how the insurance worked, but adapting these insurances to rural contexts represents a challenge. Perhaps simpler solutions, such as the fixedprice contracts studied in Arouna et al. (2021), may reduce risk exposure and improve farmers' outcomes. Second, future lab-in-the-field experiments can shed light on optimal subsidies delivered as vouchers by turning effort supply into one of the participants' decisions. 


\section{References}

Alderman, H., Hoddinott, J., and Kinsey, B. (2006). Long term consequences of early childhood malnutrition. Oxford Economic Papers, 58(3):450-474.

Arouna, A., Michler, J. D., and Lokossou, J. C. (2021). Contract farming and rural transformation: Evidence from a field experiment in Benin. Journal of Development Economics, 151:102626.

Ashraf, N., Giné, X., and Karlan, D. (2009). Finding missing markets (and a disturbing epilogue): Evidence from an export crop adoption and marketing intervention in Kenya. American Journal of Agricultural Economics, 91(4):973-990.

Beam, E. (2016). Do job fairs matter? experimental evidence on the impact of job-fair attendance. Journal of Development Economics, 120:32-40.

Benjamin, D. (1992). Household composition, labor markets, and labor demand: testing for separation in agricultural household models. Econometrica: Journal of the Econometric Society, pages $287-322$.

Besley, T. (1994). How do market failures justify interventions in rural credit markets? The World Bank Research Observer, 9(1):27-47.

Burchardi, K., De Quidt, J., Gulesci, S., Lerva, B., and Tripodi, S. (2021). Testing willingness to pay elicitation mechanisms in the field: Evidence from Uganda. Journal of Development Economics, page 102701.

Casaburi, L. and Macchiavello, R. (2019). Demand and supply of infrequent payments as a commitment device: evidence from Kenya. American Economic Review, 109(2):523-55.

Cohen, A. and Einav, L. (2003). The effects of mandatory seat belt laws on driving behavior and traffic fatalities. Review of Economics and Statistics, 85(4):828-843.

Cohen, J. and Dupas, P. (2010). Free distribution or cost-sharing? evidence from a randomized malaria prevention experiment. The Quarterly Journal of Economics, pages 1-45.

Collins, D., Morduch, J., Rutherford, S., and Ruthven, O. (2009). Portfolios of the Poor. Princeton University Press.

Cortés, D., Gallegos, A., and Perez, J. E. P. (2021). The spending responses to adverse health shocks: Evidence from a panel of Colombian households.

De Janvry, A., Sadoulet, E., and Suri, T. (2017). Field experiments in developing country agriculture. In Handbook of Economic Field Experiments, volume 2, pages 427-466. Elsevier.

Dohmen, T., Falk, A., Huffman, D., Sunde, U., Schupp, J., and Wagner, G. G. (2011). Individual risk attitudes: Measurement, determinants, and behavioral consequences. Journal of the European Economic Association, 9(3):522-550. 
Duflo, E., Kremer, M., and Robinson, J. (2011). Nudging farmers to use fertilizer: Theory and experimental evidence from kenya. American Economic Review, 101(6):2350-90.

Dupas, P. (2014). Getting essential health products to their end users: Subsidize, but how much? Science, 345(6202):1279-1281.

Evans, W. N. and Graham, J. D. (1991). Risk reduction or risk compensation? the case of mandatory safety-belt use laws. Journal of Risk and Uncertainty, 4(1):61-73.

Fafchamps, M. (1993). Sequential labor decisions under uncertainty: An estimable household model of West-African farmers. Econometrica: Journal of the Econometric Society, pages 11731197.

Fink, G., Jack, B. K., and Masiye, F. (2020). Seasonal liquidity, rural labor markets, and agricultural production. American Economic Review, 110(11):3351-92.

Gáfaro, M., Ibáñez, A. M., and Zarruk, D. (2012). Equidad y eficiencia rural en Colombia: una discusión de políticas para el acceso a la tierra. Technical report.

Grumiau, S. (2012). Formalizing domestic work through the use of service vouchers: The particular cases of France, Belgium and the canton of Geneva. ILO Bureau for workers' activities (ACTRAV).

Hoffmann, B. (2018). Do non-monetary prices target the poor? evidence from a field experiment in India. Journal of Development Economics, 133:15-32.

Jacoby, H. G. (1993). Shadow wages and peasant family labour supply: an econometric application to the Peruvian Sierra. The Review of Economic Studies, 60(4):903-921.

Jayachandran, S. (2006). Selling labor low: Wage responses to productivity shocks in developing countries. Journal of Political Economy, 114(3):538-575.

Karlan, D. and Morduch, J. (2010). Access to finance. In Handbook of Development Economics, volume 5, pages 4703-4784. Elsevier.

Karlan, D., Osei, R., Osei-Akoto, I., and Udry, C. (2014). Agricultural decisions after relaxing credit and risk constraints. The Quarterly Journal of Economics, 129(2):597-652.

Marx, I. and Vandelannoote, D. (2015). Matthew runs amok: The Belgian service voucher scheme. In The political economy of household services in Europe, pages 197-220. Springer.

Otero-Cortés, A. (2019). El mercado laboral rural en Colombia, 2010-2019. Documento de Trabajo sobre Economía Regional y Urbana; No. 281.

Rose, E. (1999). Consumption smoothing and excess female mortality in rural india. Review of Economics and statistics, 81(1):41-49.

Schickele, A. (2016). Make it rain. Cambridge, MA: Abdul Latif Jameel Poverty Action Lab, Center for Effective Global Action, and Agricultural Technology Adoption Initiative. 
Online Appendix

The trade-off between liquidity and insurance: voucher payments in a lab-in-the-field experiment with Colombian rural workers

\author{
Alexander Cand 1 , Darwin Cortés ${ }^{2}$, César Mantilla ${ }^{3}$, Laura Prada \\ and Medardo Restrepo 5 \\ Data availability \\ The data and code to replicate these tables and figures, as well as those in the manuscript, can be \\ found at https://osf.io/rp4xa/
}

\title{
A Additional Tables and Figures
}

Table A.1: Participants by municipality in the field sample

\begin{tabular}{lccc}
\hline Municipality & Frequency & Percent & Order \\
\hline Buenavista & 20 & 9.35 & Descending \\
Calarcá & 23 & 10.75 & Ascending \\
Circasia & 19 & 8.88 & Ascending/Descending \\
Córdoba & 22 & 10.28 & Ascending \\
Filandia & 18 & 8.41 & Descending \\
Génova & 20 & 9.35 & Ascending \\
La Tebaida & 24 & 11.21 & Ascending \\
Montenegro & 20 & 9.35 & Ascending \\
Pijao & 20 & 9.35 & Descending \\
Quimbaya & 20 & 9.35 & Descending \\
Salento & 8 & 3.74 & Descending \\
\hline
\end{tabular}

${ }^{1}$ Justus-Liebig-Universität Giessen.

${ }^{2}$ Department of Economics, Universidad del Rosario and Alianza EFI.

${ }^{3}$ Department of Economics, Universidad del Rosario.

${ }^{4}$ Department of Economics, Universidad del Rosario.

${ }^{5}$ Centro de Pensamiento, Universidad del Quindío. 
Table A.2: Balance test by treatment dimension - Field sample

\begin{tabular}{lcccccc}
\hline & \multicolumn{3}{c}{ Order dimension } & \multicolumn{3}{c}{ Fee dimension } \\
& $\begin{array}{c}\text { Mean } \\
\text { Ascendent }\end{array}$ & $\begin{array}{c}\text { Mean } \\
\text { Descendent }\end{array}$ & $p$-value & Mean & Mean & $p$-value \\
& 47.98 & 55.05 & $(0.002)$ & 51.68 & 50.61 & $(0.646)$ \\
Age & 0.33 & 0.34 & $(0.839)$ & 0.35 & 0.32 & $(0.703)$ \\
Women & 0.25 & 0.16 & $(0.081)$ & 0.18 & 0.24 & $(0.329)$ \\
Married & 13.07 & 13.19 & $(0.130)$ & 13.14 & 13.11 & $(0.721)$ \\
Income (log) & 0.32 & 0.25 & $(0.250)$ & 0.27 & 0.31 & $(0.439)$ \\
Payment in kind & 0.27 & 0.31 & $(0.510)$ & 0.31 & 0.27 & $(0.468)$ \\
Government's subsidy & 0.19 & 0.23 & $(0.543)$ & 0.20 & 0.22 & $(0.759)$ \\
Monthly salary & 0.50 & 0.61 & $(0.095)$ & 0.57 & 0.53 & $(0.604)$ \\
Elementary school & 2.90 & 2.64 & $(0.169)$ & 2.78 & 2.78 & $(0.995)$ \\
Household adults & 0.69 & 0.59 & $(0.497)$ & 0.73 & 0.55 & $(0.181)$ \\
Household kids & 4.05 & 4.14 & $(0.833)$ & 4.20 & 3.97 & $(0.561)$ \\
Siblings & 0.17 & 0.28 & $(0.050)$ & 0.22 & 0.22 & $(0.984)$ \\
Contributory scheme & 0.66 & 0.55 & $(0.105)$ & 0.61 & 0.62 & $(0.840)$ \\
Without old age plan & 5.66 & 6.19 & $(0.180)$ & 5.83 & 5.96 & $(0.742)$ \\
Willingness to take risks & 0.51 & 0.42 & $(0.206)$ & 0.50 & 0.44 & $(0.368)$ \\
Debts & 0.71 & 0.60 & $(0.104)$ & 0.70 & 0.62 & $(0.192)$ \\
Community support network & 0.34 & 0.40 & $(0.392)$ & 0.39 & 0.34 & $(0.521)$ \\
Land owner & 0.56 & 0.63 & $(0.334)$ & 0.60 & 0.58 & $(0.820)$ \\
Shocks & 0.45 & 0.56 & $(0.113)$ & 0.54 & 0.47 & $(0.307)$ \\
Health problems & & & & & &
\end{tabular}


Table A.3: Balance test by treatment dimension - Students sample

\begin{tabular}{|c|c|c|c|c|c|c|}
\hline & \multicolumn{3}{|c|}{ Order dimension } & \multicolumn{3}{|c|}{ Fee dimension } \\
\hline & $\begin{array}{c}\text { Mean } \\
\text { Ascending }\end{array}$ & $\begin{array}{c}\text { Mean } \\
\text { Descending }\end{array}$ & $p$-value & $\begin{array}{l}\text { Mean } \\
\text { Cash }\end{array}$ & $\begin{array}{c}\text { Mean } \\
\text { Voucher }\end{array}$ & $p$-value \\
\hline Age & 24.97 & 24.03 & $(0.558)$ & 23.91 & 25.09 & $(0.465)$ \\
\hline Women & 0.46 & 0.59 & $(0.283)$ & 0.56 & 0.49 & $(0.550)$ \\
\hline Married & 0.11 & 0.06 & $(0.421)$ & 0.06 & 0.11 & $(0.421)$ \\
\hline Income(Log) & 13.46 & 13.20 & $(0.295)$ & 13.36 & 13.30 & $(0.806)$ \\
\hline Government's subsidy & 0.23 & 0.18 & $(0.597)$ & 0.18 & 0.23 & $(0.597)$ \\
\hline Monthly salary & 0.43 & 0.53 & $(0.409)$ & 0.47 & 0.49 & $(0.902)$ \\
\hline Household adults & 2.51 & 3.06 & $(0.069)$ & 2.68 & 2.89 & $(0.490)$ \\
\hline Household kids & 0.49 & 0.53 & $(0.808)$ & 0.47 & 0.54 & $(0.688)$ \\
\hline Siblings & 2.17 & 1.59 & $(0.081)$ & 1.38 & 2.37 & $(0.002)$ \\
\hline Contributory scheme & 0.46 & 0.62 & $(0.187)$ & 0.59 & 0.49 & $(0.401)$ \\
\hline Without old age plan & 0.66 & 0.56 & $(0.410)$ & 0.68 & 0.54 & $(0.262)$ \\
\hline Willingness to take risks & 7.77 & 7.94 & $(0.625)$ & 7.82 & 7.89 & $(0.858)$ \\
\hline Debts & 0.60 & 0.65 & $(0.692)$ & 0.68 & 0.57 & $(0.375)$ \\
\hline Community support network & 0.69 & 0.62 & $(0.560)$ & 0.65 & 0.66 & $(0.931)$ \\
\hline Land owner & 0.46 & 0.56 & $(0.406)$ & 0.44 & 0.57 & $(0.286)$ \\
\hline Shocks & 0.51 & 0.62 & $(0.394)$ & 0.62 & 0.51 & $(0.394)$ \\
\hline Health problems & 0.57 & 0.59 & $(0.890)$ & 0.62 & 0.54 & $(0.536)$ \\
\hline
\end{tabular}


Table A.4: Tobit model for the field sample with covariates of interest in an exploratory analysis.

\begin{tabular}{lccc}
\hline & $(1)$ & $(2)$ & $(3)$ \\
VARIABLES & Price of minimum accepted voucher \\
\hline & & & \\
Show-up fee in voucher & 0.283 & 0.317 & 0.358 \\
& $(0.745)$ & $(0.716)$ & $(0.733)$ \\
Descending order & $-3.432^{* * *}$ & $-3.337^{* * *}$ & $-3.174^{* * *}$ \\
Women & $(0.854)$ & $(0.963)$ & $(0.967)$ \\
Age & & $-1.478^{* *}$ & -0.946 \\
& & $(0.729)$ & $(0.829)$ \\
Primary school or less & & -0.0263 & -0.0115 \\
Married & & $(0.0331)$ & $(0.0327)$ \\
Willingness to take risks & & 0.674 & 0.649 \\
& & $(1.086)$ & $(1.111)$ \\
Agricultural laborer & & -0.109 & -0.167 \\
& & $(1.092)$ & $(1.080)$ \\
Monthly salary & & $-0.302^{* *}$ & $-0.381^{* * *}$ \\
Government's subsidy & & $(0.127)$ & $(0.129)$ \\
Payment-in-kind & & 1.569 & 1.453 \\
Constant & & $(0.994)$ & $(0.940)$ \\
Observations & & & -1.363 \\
\hline
\end{tabular}

All regressions included municipal-level covariates and a dummy for session order within a municipality. Standard errors clustered at the session level in parentheses. ${ }^{* * *}$ $\mathrm{p}<0.01,{ }^{* *} \mathrm{p}<0.05,{ }^{*} \mathrm{p}<0.1$ 
Figure A.1: Voucher take-up rates in the field and students' sample between treatment conditions.

(a) Take-up comparison between samples

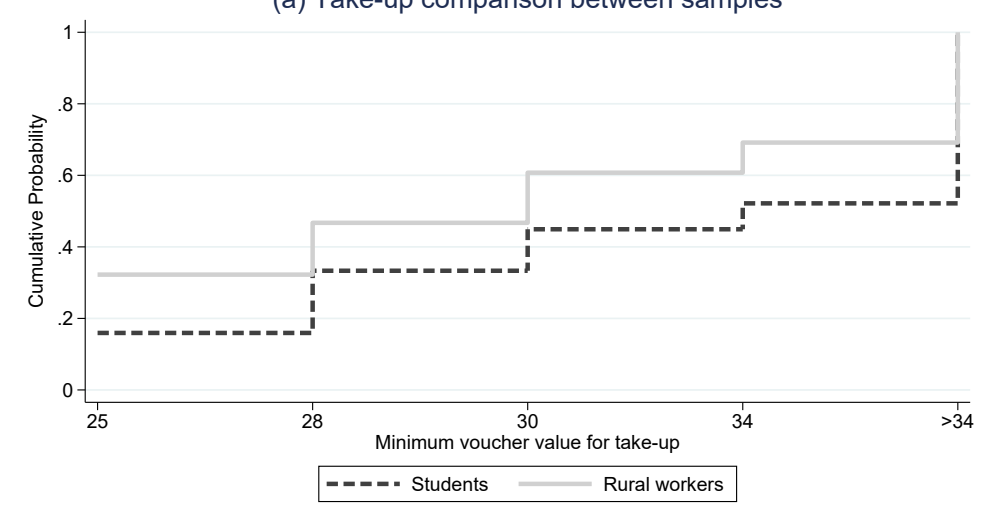

(b) Take-up comparison for rural sample by fee type

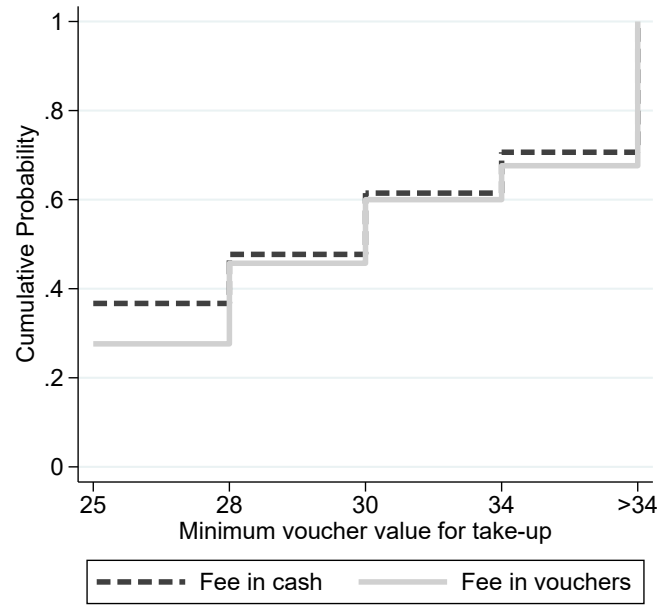

(d) Take-up comparison for rural sample by order

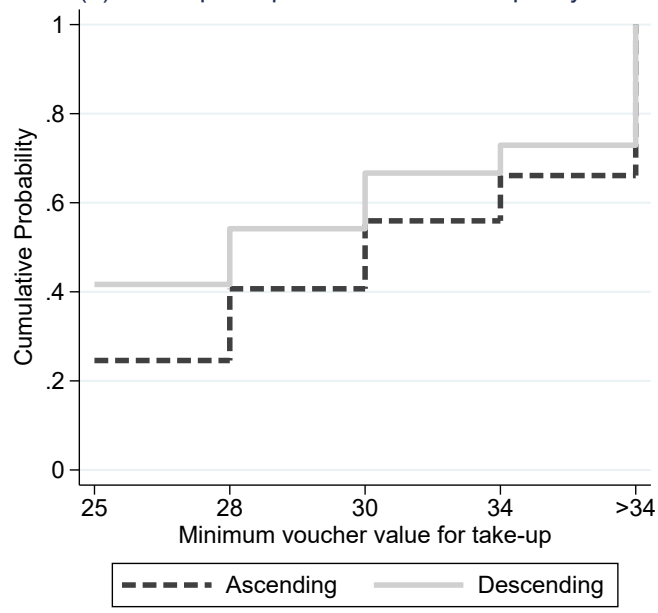

(c) Take-up comparison for students' sample by fee typ

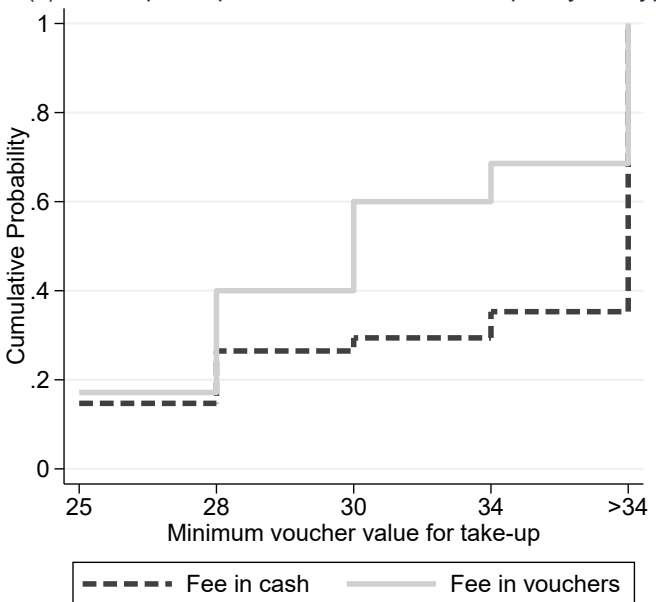

(e) Take-up comparison for students' sample by order

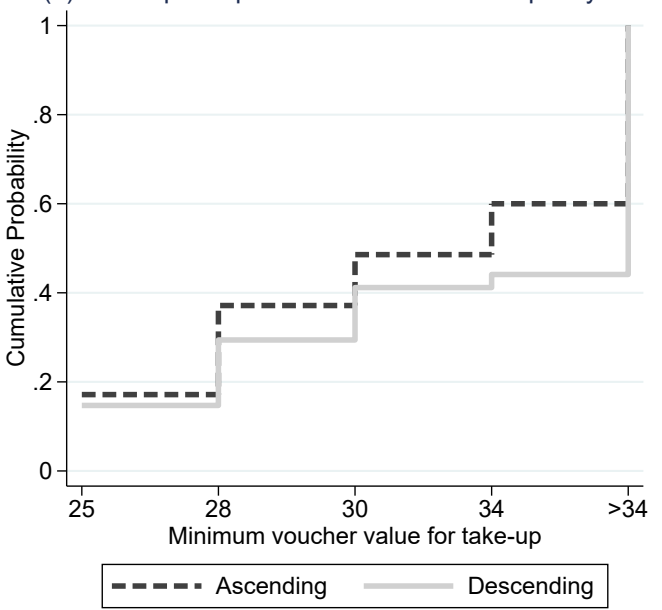


Figure A.2: Margin analysis from the ordered logit model. Marginal effects computed after the estimation in column 3 from Table 2 .

(a) By type of show-up fee payment

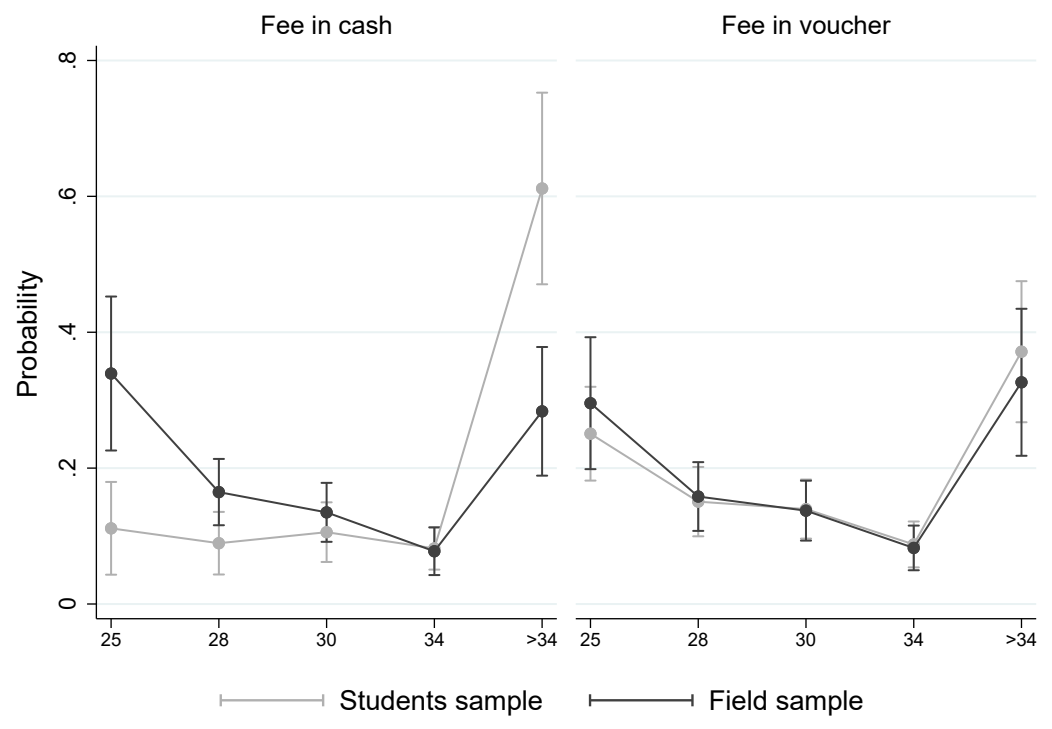

(b) By ascending/descendign order

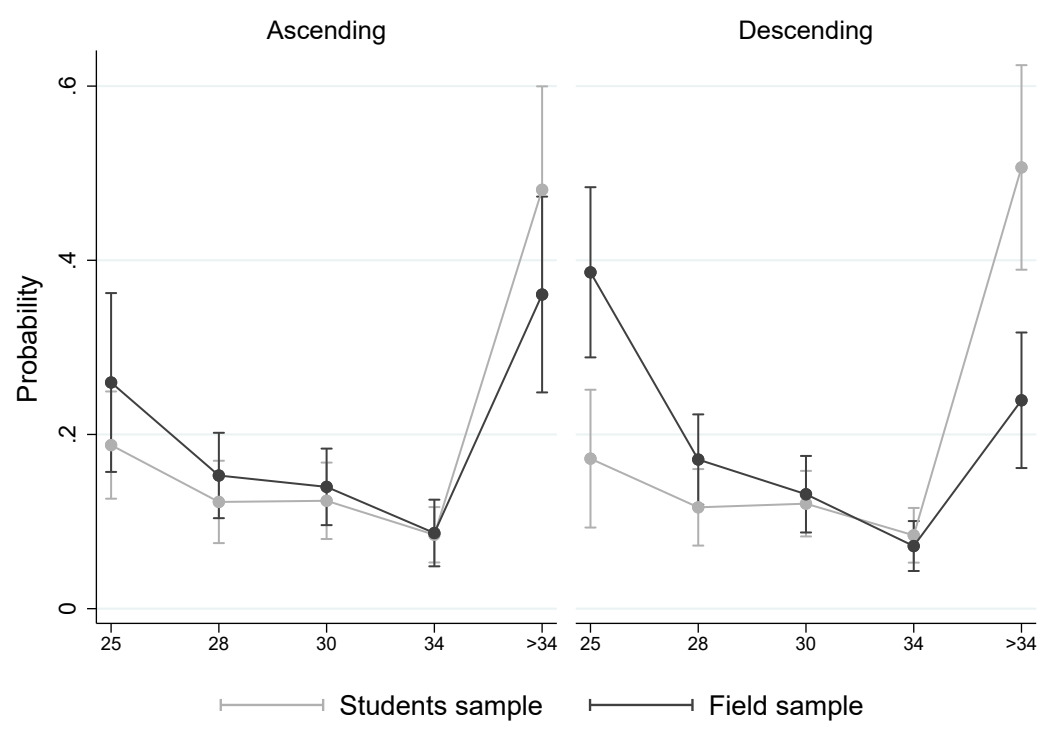




\section{B Experimental Protocol: Translated Version}

\section{General instructions}

Welcome. We appreciate that you accepted the invitation to this activity that will last around 60 minutes. This time includes the explanation of the activity, the time in which you make your decisions, and a short survey. In this activity, your decisions have economic consequences to make them more similar to the decisions you make in your daily life. Winnings from this game are not paid for participating, so we hope that you will participate in future activities of other researchers, even if no winnings are involved.

The funds to cover these expenses have been provided by the Universidad del Rosario and Universidad del Quindío within the framework of a project on labor markets financed by the Ministry of Sciences. The information collected will be anonymized and only those responsible for the project will have access to it.

\section{Initial profit for participating}

Just for participating, answering a survey and staying until the end you will win $\$ 10,000$. This money will be given to you [in cash/vouchers, whose redemption at a nearby supermarket will be explained below].

Additionally, you will complete a task that will take between 5 and 10 minutes. You will be able to choose between two payment schemes for carrying out this task.

> In the treatment with show-up fee paid as a voucher, display the voucher.<<

\section{Pay in cash or vouchers?}

We want to understand if you prefer cash or voucher payment.

You can exchange the vouchers after finishing the activity for food or toiletries at the supermarket [NAME OF SUPERMARKET,] which is located [DESCRIPTION IN TIME/DISTANCE ON HOW TO GET THERE].

At the end of the activity we will throw a die that has 4 green faces, 1 red face and 1 white face.

> Show dice and their respective faces.<<

If you receive your winnings in cash, the roll of the dice is the only thing that determines your winnings. If it lands on the red side, it will cause you to lose $\$ 20,000$ of your winnings.

If you receive your winnings as tokens, you will roll the dice first. If the die lands on the red side, you will be able to flip a coin that works as "insurance".

If the coin lands on the green side, it will prevent you from losing $\$ 20,000$ of your winnings. In other words, receiving the winnings in vouchers halves your chances of losing that $\$ 20,000$. The white side of the die has no function. If the white face comes up when rolling the die, the die will be rolled again until a green or red face comes up. Payment in vouchers can only be spent on food 
or toiletries at the supermarket, but in return you have an "insurance", which reduces the chances that a negative event will reduce your earnings by $\$ 20,000$.

Since we are interested in how much money in vouchers makes this option interesting to you, we will make the decision to keep cash or vouchers four times. The amount offered as vouchers will change, while the cash payment will be fixed. In the end, we will choose one of four random decisions to calculate your payouts.

Now we are going to explain what is the task that you will have to carry out in order to receive the earnings of the activity.

\section{Explanation of the separate bean task}

You will receive a bag of beans and two small buckets. You must separate the red grains, which will go into the small bucket, from the white grains, which you will leave in the big bucket.

We will indicate the level until which the small buckets should be filled. You will need to complete this task in order to receive any earnings from the activity. It doesn't matter how long it takes you to complete it, but it's important that you do it as quickly as possible because we won't be able to continue until everyone has finished. We will measure the time it takes you to complete the task, but this will not affect your earnings.

>>Show the buckets and the tape or line to which they are expected to be filled.<<

\section{Explanation of the decision-making process}

Now we are going to explain in detail how the decision-making will be. You have received a plastic card with the number 1, this means that with this card you will make the Decision \#1.

> Show the card with Decision \#1 . <

\section{(this card is similar to the left panel of Figure 1 )}

If you choose CASH, you can win $\$ 30,000$ if one of the 4 green sides of the die comes up, or $\$ 10,000$ if the red side of the die comes up. If you choose the VOUCHERS, you can win $\$ 34,000$ if one of the 4 green faces of the dice comes up. If the red side of the die comes up, you have an "insurance" that will allow you to flip the coin. If the coin lands on the green side, you will win $\$ 34,000$. If the coin lands on the red side, you will win $\$ 14,000$. After making this decision, you can remove the other three laminated cards from the envelope, as we indicate.

\section{Summary of instructions}

This poster summarizes the stages of the activity.

> Show the poster and explain each stage of the activity.<< 


\section{(the poster corresponds to the right panel of Figure 1)}

First, we are going to read and sign the Informed Consent. This is a document in which you declare that you are here at your will, that you have understood the instructions of the activity, and that you will comply with the biosafety instructions. In exchange, we declare that the data will be used confidentially and for purely academic purposes, and that we will make the promised payments.

Then, we are going to make the four decisions. Remember that they are very similar decisions, except that the amount we offer you in VOUCHERS will change, whereas the amount in CASH will be fixed. Once you make all four decisions, you will do the task of separating coffee beans.

One you take all the decisions and complete the task, you will draw one ball corresponding to the decision number we will pay to you. Once we have the selected decision, we will roll the dice and flip the coin to compute your payment. Finally, while we calculate your earnings and prepare the receipt for you to sign, we will ask you to complete a survey.

\section{Reading and signing the informed consent}

> Ask participants to remove the informed consent form from the envelope.

Read the consent aloud and ask them to sign it.

Check that all participants signed. $<<$

\section{Making the first decision}

Now that we've signed informed consent, let's quickly review the decision-making process.

>Ask participants to remove card number 1 from the envelope.

Check in each decision that the card outside corresponds to the decision announced out loud. $<<$

You have received a plastic card to make Decision \#1. If you choose CASH, you can win $\$ 30,000$ if one of the 4 green sides of the die comes up, or $\$ 10,000$ if the red side of the die comes up. If you choose the VOUCHERS, you can win $\$ 34,000$ if one of the 4 green faces of the dice comes up. If the red side of the die comes up, you have an "insurance" that will allow you to flip the coin. If the coin lands on the green side, you will win $\$ 34,000$. If the coin lands on the red side, you will win $\$ 14,000$.

Please use the marker to make an " $X$ " on the option you prefer, CASH or VOUCHERS. Once all the participants keep their marked card in the envelope, we will move on to the second decision.

>>Collect card \#1 and fill out the session registration.<<

\section{Making the second to fourth decisions}

> Read again the consequences of choosing cash or voucher.

The script for decision making \#2 through \#4 can be a bit repetitive. 
It can be shortened if it is considered that the participants understood after the first decision.

Pick up the corresponding card and fill out the session registration.<<

\section{Performing the bean separation task}

You have already made all four decisions. Now we are going to give you the bag with beans and the two buckets. Please do not start until we tell you to. Remember to separate the red grains, which should go into the small bucket, from the white grains. For this, you will not be able to spread the beans on the table/chair you are on.

You will need to complete the task to receive the earnings from the activity. No matter how long it takes you to complete it, but we won't be able to continue until everyone has finished. We will measure the time it takes you to complete the task, but this will not affect your earnings.

\section{Payment computation: choice selection, dice roll and coin toss}

We will now decide which of the four tasks will be used to calculate the earnings for each participant. The monitor will approach you, and you will draw a ball from the bag. Each ball is marked with a number from 1 to 4 . The number you roll will correspond to the decision that we will pay you.

After having defined the decision that will be paid, you will roll the dice. If the red side of the die comes up and you chose the CASH payout for that decision, you will lose $\$ 20,000$ of your payout. If the red side of the die lands and you chose the VOUCHER payout for that decision, you will flip a coin. Only if the coin also lands on the red side will you lose $\$ 20,000$ of your payout. If the white face lands when the die is rolled, it will be repeated until the roll lands a green or red face.

\section{Survey and final payments}

While we finish calculating your earnings, one of the monitors will help you filling a survey. We will ask you for characteristics about yourself, your work and your home. Remember that all information collected within this activity, including your responses to the survey, will be used confidentially and solely for the purposes of this research.

\section{Voucher redemption}

You have received the payment for the activity in a voucher. You can redeem it for food or toiletries at the supermarket [NAME OF SUPERMARKET.]

Once you have decided how to spend the vouchers, you can approach one of the activity monitors in the supermarket, hand over the vouchers, and claim the desired items. If you want to spend some of the initial money you received for your participation in the store, you can do that too. 


\section{Experimental Protocol: Original (Spanish) Version}

\section{Instrucciones generales}

Bienvenidos. Agradecemos que aceptaran la invitación a esta actividad que durará alrededor de 60 minutos. Este tiempo incluye la explicación de la actividad, la toma de sus decisiones, y una breve encuesta. En esta actividad sus decisiones tienen consecuencias económicas, de modo que sean más parecidas a las decisiones que toma en su vida diaria. Las ganancias que usted se lleve en este juego no corresponden a un pago por participar, por lo que esperamos que participe en futuras actividades de otros investigadores, aún si no hay ganancias de por medio.

Los fondos para cubrir estos gastos han sido proporcionados por la Universidad del Rosario y Universidad del Quindío en el marco de un proyecto sobre mercados laborales financiado por MinCiencias. La información recolectada será anonimizada y solo los responsables del proyecto tendrán acceso a ella.

\section{Ganancia inicial por participar}

Por el sólo hecho de participar, responder una encuesta y quedarse hasta el final usted ganará $\$ 10.000$. Este dinero se le entregará [en efectivo/en vales, cuyo canje en un supermercado cercano se explicará a continuación].

Adicionalmente, usted hará una tarea que le tomará entre 5 y 10 minutos. Usted podrá escoger entre dos esquemas de pago por la realización de esta tarea.

>Display the voucher in the treatment with show-up fee paid in voucher.<<

\section{¿Pago en efectivo o en vales?}

Queremos entender si usted prefiere un pago en efectivo o en vales.

Los vales los podrá intercambiar tras finalizar la actividad por alimentos o artículos de aseo en el supermercado [NOMBRE DEL SUPERMERCADO,] que está ubicado [DESCRIPCIÓN EN TIEMPO/DISTANCIA SOBRE CÓMO LLEGAR].

Al final de la actividad lanzaremos un dado que tiene 4 caras verdes, 1 cara roja y 1 cara blanca.

$>$ Mostrar dado y sus respectivas caras. $<<$

Si usted recibe sus ganancias en efectivo, el lanzamiento del dado es lo único que determina sus ganancias. Si cae por la cara roja, hará que usted pierda $\$ 20.000$ de sus ganancias.

Si usted recibe sus ganancias como vales, usted lanzará primero el dado. Si el dado cae por la cara roja, usted podrá lanzar una moneda que funciona como un "seguro".

Si la moneda cae por la cara verde, evitará que usted pierda $\$ 20.000$ de sus ganancias. Dicho de otro modo, recibir las ganancias en vales reduce a la mitad sus chances de perder esos $\$ 20.000$. La cara blanca del dado no tiene ninguna función. Si cae la cara blanca al lanzar el dado, se lanzará de nuevo el dado hasta que caiga una cara verde o roja. El pago en vales sólo lo puede gastar en 
alimentos o artículos de aseo en el supermercado, pero a cambio tiene el "seguro", que reduce los chances de que un evento negativo reduzca sus ganancias en $\$ 20.000$.

Como nos interesa saber qué cantidad de dinero en vales hace que esta opción sea interesante para usted, tomaremos cuatro veces la decisión de quedarse con el efectivo o con los vales. El monto ofrecido como vales irá cambiando, mientras el pago en efectivo será fijo. Al final, escogeremos una de las cuatro decisiones al azar para calcular sus pagos.

Ahora vamos a explicar cuál es la tarea que deberán realizar para poder recibir las ganancias de la actividad.

\section{Explicación de la tarea de separar frijol}

Usted va a recibir una bolsa con granos de frijol y dos pequeños baldes. Usted debe separar los granos rojos, que irán al balde pequeños, de los granos blancos, que dejará en el balde grande.

A continuación le indicaremos hasta dónde deben ser llenados los baldes pequeños. Usted deberá completar esta tarea para poder recibir las ganancias de la actividad. No importa cuánto tiempo le tome completarla, pero es importante que la realice lo más rápido posible porque no podremos continuar hasta que todos hayan terminado. Nosotros mediremos el tiempo que le tome terminar la tarea, pero esto no afectará sus ganancias.

>Mostrar los baldes y la cinta o la línea hasta la cual se espera que sean

llenados. $<<$

\section{Explicación de la toma de decisiones}

Ahora vamos a explicar en detalle cómo será la toma de decisiones. Usted ha recibido una tarjeta plastificada con el número 1, esto quiere decir que con esta tarjeta tomará la Decisión \#1.

>>Mostrar la tarjeta con la Decisión \#1 . <

\section{(this card is similar to the left panel of Figure 1)}

Si usted escoge el EFECTIVO, puede ganar $\$ 30.000$ si sale una de las 4 caras verdes del dado, o $\$ 10.000$ si sale la cara roja del dado. Si usted escoge los VALES, puede ganar $\$ 34.000$ si sale una de las 4 caras verdes del dado. Si sale la cara roja del dado, usted tiene el "seguro" que le permitirá lanzar la moneda. Si la moneda cae por la cara verde, ganará $\$ 34.000$. Si la moneda cae por la cara roja, ganará $\$ 14.000$. Luego de tomar esta decisión usted podrá sacar del sobre las otras tres tarjetas plastificadas, según le vayamos indicando.

\section{Resumen de las instrucciones}

Este afiche resume las etapas de la actividad.

>>Mostrar el afiche y explicar cada etapa de la actividad.<< 


\section{(the poster corresponds to the right panel of Figure 1)}

Primero, vamos a leer y firmar el Consentimiento Informado. Este es un documento en el que ustedes declaran que están aquí bajo su voluntad, que han entendido las instrucciones del ejercicio, y que cumplirán con las instrucciones de bioseguridad. A cambio, nosotros declaramos que los datos serán utilizados de forma confidencial y con fines puramente académicos, y que realizaremos los pagos prometidos.

Después, vamos a tomar las cuatro decisiones. Recuerde que son decisiones muy parecidas, excepto que el monto que le ofrecemos en VALES irá cambiando, y el monto en EFECTIVO estará fijo. Una vez tome las cuatro decisiones, usted hará la tarea de separar granos de café.

Una vez usted tome las decisiones y complete la tarea, usted sacará una bola cuyo número corresponderá a la decisión con la que calcularemos su pago. Una vez seleccionada la decisión que le pagaremos, realizaremos el lanzamiento del dado y de la moneda para calcular sus ganancias. Finalmente, mientras calculamos sus ganancias y preparamos el recibo que deberá firmar, le pediremos que responda una encuesta.

\section{Lectura y firma del consentimiento informado}

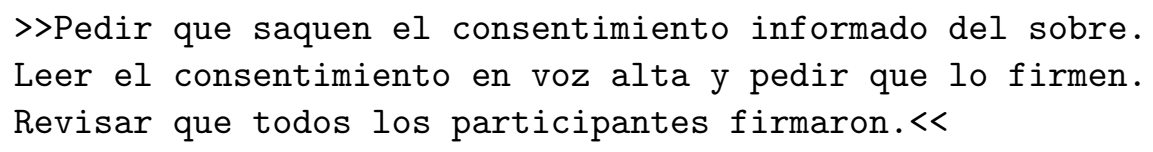

\section{Toma de la primera decisión}

Ahora que hemos firmado el consentimiento informado repasemos rápidamente la toma de decisiones.

>Pedir que saquen la tarjeta numero 1 del sobre.

Revisar en cada decisión que la tarjeta afuera sea la correspondiente a la decisión anunciada en voz alta. $<<$

Usted ha recibido una tarjeta plastificada para tomar la Decisión \#1. Si usted escoge el EFECTIVO, puede ganar $\$ 30.000$ si sale una de las 4 caras verdes del dado, o $\$ 10.000$ si sale la cara roja del dado. Si usted escoge los VALES, puede ganar $\$ 34.000$ si sale una de las 4 caras verdes del dado. Si sale la cara roja del dado, usted tiene el "seguro" que le permitirá lanzar la moneda. Si la moneda cae por la cara verde, ganará \$34.000. Si la moneda cae por la cara roja, ganará \$14.000.

Por favor use el marcador para hacer una " $X$ " en la opción que prefiere, el EFECTIVO o los VALES. Una vez todos los participantes guarden en el sobre su tarjeta marcada, pasaremos a la segunda decisión.

>>Recoger la tarjeta \#1 y diligenciar el registro de la sesión. $<<$ 


\section{Toma de la segunda a cuarta decisión}

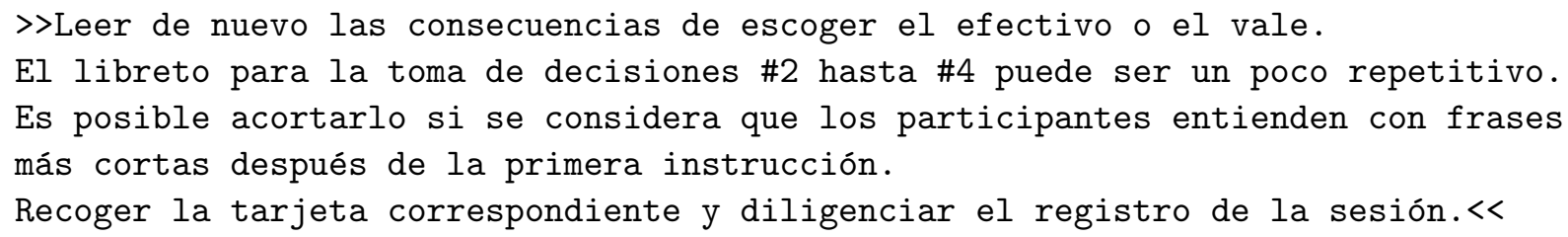

\section{Realización de la tarea de separar frijol}

Usted ya tomó las cuatro decisiones. Ahora vamos a entregarle la bolsa con granos de frijol y los dos baldes. Por favor no comience hasta que se lo indiquemos. Recuerde que debe separar los granos rojos, que deberán ir al balde pequeño, de los granos blancos. Para esto, usted no podrá regar los granos de frijol sobre la mesa/silla sobre la que se encuentra.

Usted deberá completar la tarea para recibir las ganancias de la actividad. No importa cuánto tiempo le tome completarla, pero no podremos continuar hasta que todos hayan terminado. Nosotros mediremos el tiempo que le tome terminar la tarea, pero esto no afectará sus ganancias.

\section{Elección de la decisión a pagar, lanzamiento del dado y la moneda}

Ahora decidiremos cuál de las cuatro tareas se utilizará para calcular las ganancias de cada uno. El monitor se acercará a usted, y usted sacará una bola de la bolsa. Cada bola está marcada con un número del 1 al 4 . El número que saque corresponderá a la decisión que le pagaremos.

Tras haber definido la decisión que será pagada, usted lanzará el dado. Si cae la cara roja del dado y usted eligió el pago en EFECTIVO para esa decisión, usted perderá \$20.000 de su pago. Si cae la cara roja del dado y usted eligió el pago en VALES para esa decisión, usted lanzará una moneda. Sólo si la moneda también cae por la cara roja usted perderá \$20.000 de su pago. Si cae la cara blanca al lanzar el dado, se repetirá hasta el lanzamiento que caiga una cara verde o roja.

\section{Encuesta y pagos finales}

Mientras terminamos de calcular sus ganancias, uno de los monitores le realizará una encuesta. Le preguntaremos por características sobre usted, su trabajo y su hogar. Recuerde que toda la información recopilada dentro de esta actividad, incluyendo sus respuestas en la encuesta, serán utilizadas de manera confidencial y únicamente con fines de esta investigación.

\section{Canje de los vales}

Usted ha recibido el pago de la actividad en vales. Usted podrá cambiarlos por alimentos o artículos de aseo en el supermercado [NOMBRE DEL SUPERMERCADO.]

Una vez haya decidido cómo gastar los vales, usted podrá acercarse a uno de los monitores de la actividad que se encuentren en el supermercado, entregarle los vales, y reclamar los artículos deseados. Si usted desea gastar parte del dinero inicial que recibió por su participación en la tienda, también podrá hacerlo. 